\author{
BULETINUL INSTITUTULUI POLITEHNIC DIN IAŞI \\ Publicat de \\ Universitatea Tehnică „Gheorghe Asachi” din Iaşi \\ Volumul 67 (71), Numărul 4, 2021 \\ Secţia \\ CONSTRUCȚII DE MAȘINI \\ DOI:10.2478/bipcm-2021-0024 \\ sciendo
}

\title{
MODELS FOR THE INFLUENCE OF TRANSMISSION ERRORS AND HOBBING FORCES UPON A COMPLEX GEAR DRIVE
}

BY

\author{
EUGEN MERTICARU ${ }^{1, *}$ and VASILE MERTICARU ${ }^{2}$
}

1“Gheorghe Asachi” Technical University of Iași, Faculty of Mechanical Engineering, Department of Mechanical Engineering, Mechatronics and Robotics

2"Gheorghe Asachi" Technical University of Iași, Faculty of Machine Manufacturing and Industrial Management, Department of Machine Manufacturing Technology

Received: September 10, 2021

Accepted for publication: December 14, 2021

\begin{abstract}
The paper describes a theoretical research approach that performs a dynamic study upon a complex gear transmission. The transmission errors of the gears from the considered complex gear drive are considered when kinematics is analyzed and presented. The cutting forces from a gear hobbing process, possibly driven by such a complex gear transmission, are considered when parameters of the dynamic model are mathematically evaluated and presented. The proposed model development includes the obtaining of the differential equation for kinetic energy. Some discussions are also made regarding the studied complex mechanism. Practically, mathematical models for the influence of transmission errors and hobbing forces upon the considered complex gear drive are proposed as deliverable results of the study. Final conclusions are also included in the paper. The aspects discussed in the paper are presenting utility for the design of such mechanisms or for calculating the parameters of some gear hobbing processes.
\end{abstract}

Keywords: complex gear drive; kinematic model; dynamic model; transmission errors; gear hobbing forces.

*Corresponding author; e-mail: eugen.merticaru@ academic.tuiasi.ro (C) 2021 Eugen Merticaru et al.

This is an open access article licensed under the Creative Commons Attribution-NonCommercialNoDerivatives 4.0 International License (CC BY-NC-ND 4.0). 


\section{Introduction}

The present paper is desired to be a continuation and a development of a previous paper (Merticaru and Merticaru, 2020).

In that paper, the authors were studying the dynamics of a complex gear transmission which could be used for gear cutting on a hobbing machine. The kinematics and the parameters of a simple dynamic model are presented. Only the overall dynamic parameters of the gear transmission are taken into account. Other parameters like elasticity of kinematic elements, meshing stiffness, friction, transmission errors or the expression of the technological forces are neglected.

In the present paper, the kinematics and the dynamics of the complex gear transmission is completed and developed by taking into account the transmission errors of the gears and the cutting forces that appear during hobbing. Such study could be useful for the designers of tool-machines and for technological engineers when calculating the cutting regime for gears machining.

There are many other works of other authors regarding the dynamics of the hobbing process. The influence of workpiece spindle vibration on hobbing accuracy is studied by Yang Y. (2019).

The torsional elastic angular displacement and its influence on hobbing process is discussed by Hrytsay I. et al. (2019).

The errors of the kinematic chain of the gears cutting machines are discussed by Mazuru S. (2019).

The necessity of developing more complex dynamic models for studying the work of mechanisms and machines are shown by Merticaru V., Merticaru E. and Merticaru V.jr. (Merticaru and Merticaru, 2004; Merticaru and Merticaru, 2020; Merticaru, 1991; Merticaru et al., 2009; Merticaru et al., 2014).

\section{Kinematic Aspects}

The complex gear transmission which is subjected to study is bellow presented in Fig 1.

Such a gear transmission could be used, for example, for manufacturing cylindrical gears by hobbing $\left(*{ }_{*}^{*}\right.$ Bazele generării suprafețelor; Iliescu, 2013; Mazuru, 2019; Tabacaru).

The complex gear presented in Fig. 1 is driven by an electric motor which is acting the wheel $z_{1}$. The flow of power is divided through gears $z_{2}$ and $z_{4}$. Then, the flow of power is divided, once again, through wheels $z_{3}{ }^{\prime}$ and $z_{10}$. The wheel $z_{9}$ has its motion as a result of linear combination of angular speeds of wheels $z_{6}{ }^{\prime}$ and $\mathrm{z}_{7}$. Also, the angular speeds of wheels $z_{9}$ and $z_{11}$ are correlated.

In the gear drive from Fig. 1, the shaft of the wheel $z_{9}$ is the workpiece spindle. The shaft of the wheel $z_{11}$ is the hob spindle. 


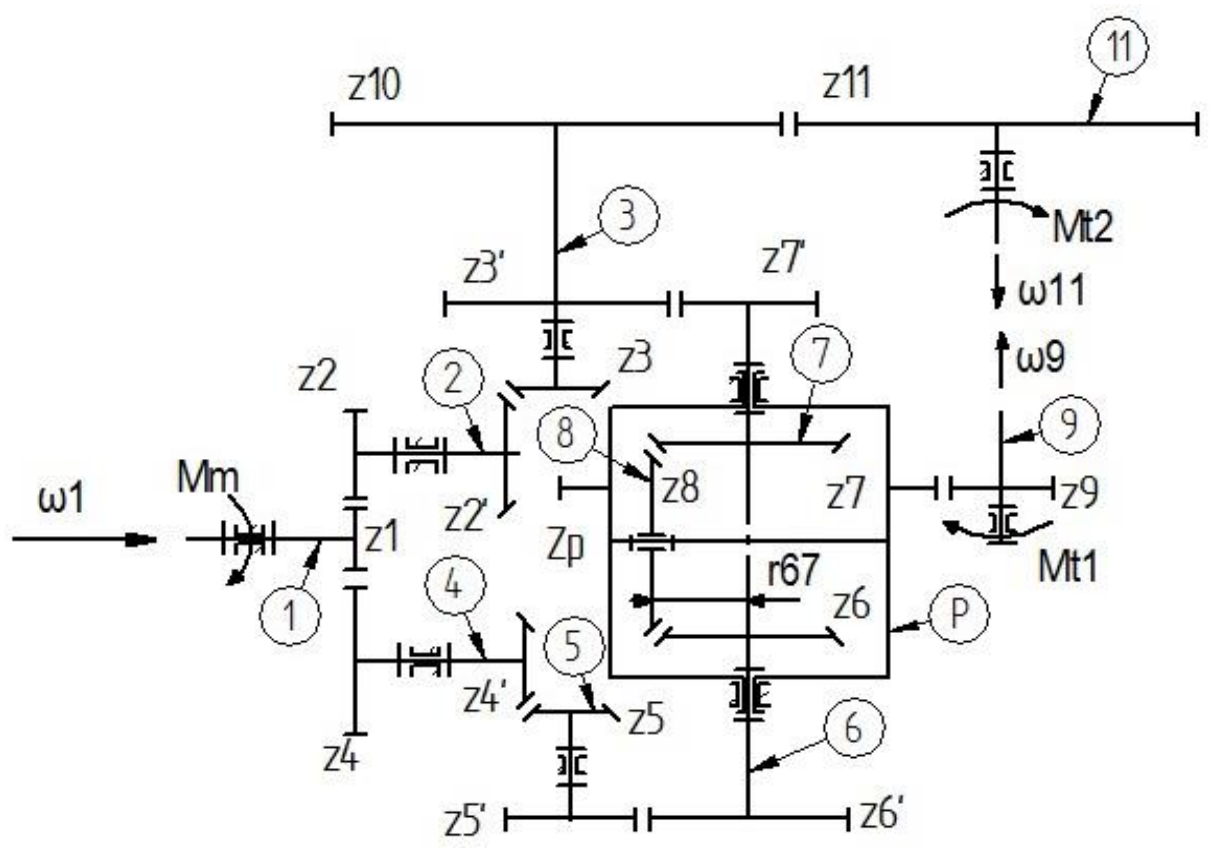

Fig. 1 - The complex gear transmission.

Usually, between the angular speeds $\omega_{9}$ and $\omega_{11}$ there is the following relation $\left(*{ }^{*}\right.$ Bazele generării suprafețelor):

$$
\frac{\omega_{9}}{\omega_{11}}=\frac{k}{z_{p s}}
$$

where: $k$ is the number of starts of the hob and $z_{p s}$ is the number of teeth of the workpiece.

The gear in Fig. 1 has 1 degree of mobility. In Fig. $1, M_{m}$ is the motor torque. $M_{t 1}$ and $M_{t 2}$ are technological torques, resulted from the cutting process, acting on wheels $z_{9}$ and, respectively $z_{11}$. Also, $z_{i}$ represents the number of teeth of wheel " $i$ ", $\omega_{i}$ represents the angular speed of wheel " $i$ ". Also, we suppose to know the inertia moments $J_{i}$ of kinematic elements " $i$ ", the mass $m_{8}$ of satellite wheel $z_{8}$, the number $n_{8}$ of the satellite wheels $z_{8}$, and the radius of disposal $r_{67}$ of the satellite wheels $z_{8}$ (shown in Fig. 1).

The transmission error of a gear is defined, as can be seen in Fig. 2 (Raghuraman, 2018; Kučera, 2018; Vispute, 2017; Atanasiu, 2010), by the following Eq. (2): 


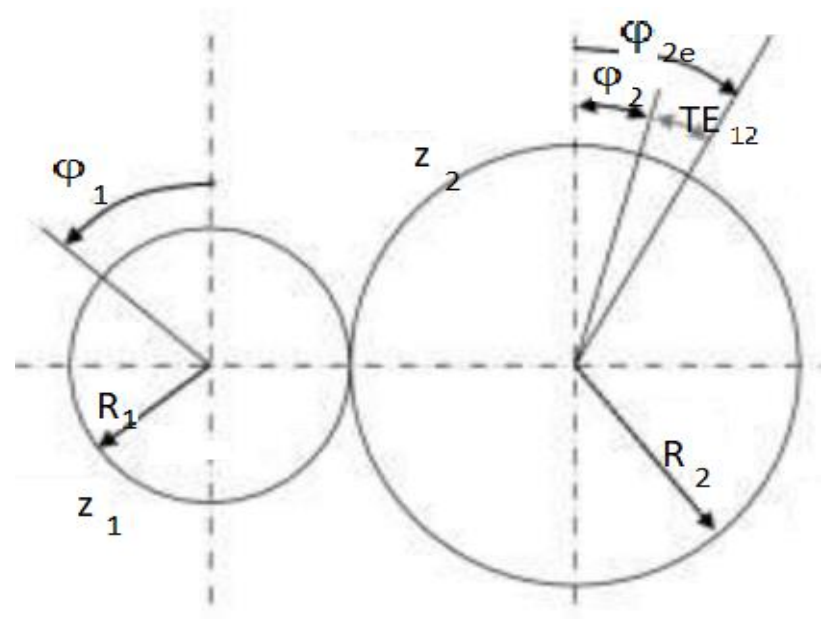

Fig. 2 - The transmission error of a gear.

$$
T E_{12}=\varphi_{2 e}-\frac{z_{1}}{z_{2}} \cdot \varphi_{1}
$$

where: $z_{1}$ is the number of teeth of the pinion, $\varphi_{1}$ is the rotation angle of the pinion, $z_{2}$ is the number of teeth of the driven gear, $\varphi_{2 e}$ is the effective rotation angle of the driven gear (affected by the transmission error $T E_{12}$ ) and $\varphi_{2}$ is the rotation angle of the driven gear unaffected by $T E_{12}$ :

$$
\varphi_{2}=\frac{z_{1}}{z_{2}} \cdot \varphi_{1}
$$

The transmission error of a gear depends on various factors such as: gearcase accuracy, gear profile accuracy, teeth spacing error of the gear, gear helix accuracy, quality of the contact surface finish, thermal distortions, gear motion, gearcase distortions, gear distortions, gear teeth deflections (Atanasiu, 2010; Kučera, 2018; Raghuraman, 2018; Vispute, 2017). That is, the transmission error is a function depending on time and angle of rotation:

$$
T E_{12}=T E_{12}\left(t, \varphi_{1}\right)
$$

By deriving in relation to time the relation (2), there can be get:

$$
T \dot{E}_{12}=\frac{d\left(T E_{12}\right)}{d t}=\omega_{2 e}-\frac{z_{1}}{z_{2}} \cdot \omega_{1}
$$


that is,

$$
\frac{\omega_{2 e}}{\omega_{1}}=\frac{T \dot{E}_{12}}{\omega_{1}}+\frac{z_{1}}{z_{2}}
$$

where $\omega_{1}$ is the angular speed of the pinion $z_{1}, \omega_{2 e}$ is the angular speed of the gear $z_{2}$ affected by the transmission error $T E_{12}$.

Like relation (6), for the complex gear in Fig. 1, the following relations can be written:

$$
\begin{aligned}
\frac{\omega_{3 e}}{\omega_{1}} & =\frac{T \dot{E}_{23}}{\omega_{1}}+\frac{z_{2}}{z_{3}} \cdot \frac{\omega_{2 e}}{\omega_{1}} \\
\frac{\omega_{11 e}}{\omega_{1}} & =\frac{T \dot{E}_{10-11}}{\omega_{1}}+\frac{z_{10}}{z_{11}} \cdot \frac{\omega_{3 e}}{\omega_{1}} \\
\frac{\omega_{4 e}}{\omega_{1}} & =\frac{T \dot{E}_{14}}{\omega_{1}}+\frac{z_{1}}{z_{4}} \\
\frac{\omega_{5 e}}{\omega_{1}} & =\frac{T \dot{E}_{4^{\prime} 5}}{\omega_{1}}+\frac{z_{4^{\prime}}}{z_{5}} \cdot \frac{\omega_{4 e}}{\omega_{1}} \\
\frac{\omega_{6 e}}{\omega_{1}} & =\frac{T \dot{E}_{5^{\prime} 6^{\prime}}}{\omega_{1}}+\frac{z_{5^{\prime}}}{z_{6^{\prime}}} \cdot \frac{\omega_{5 e}}{\omega_{1}} \\
\frac{\omega_{7 e}}{\omega_{1}} & =\frac{T \dot{E}_{3^{\prime}}}{\omega_{1}}+\frac{z_{3^{\prime}}}{z_{7^{\prime}}} \cdot \frac{\omega_{3 e}}{\omega_{1}} \\
\frac{\omega_{p e}}{\omega_{1}} & =\frac{\omega_{6 e}+\omega_{7 e}-T \dot{E}_{76}}{2 \cdot \omega_{1}}
\end{aligned}
$$

or

$$
\frac{\omega_{p e}}{\omega_{1}}=\frac{\omega_{6 e}+\omega_{7 e}-T \dot{E}_{86}-\frac{z_{8}}{z_{6}} \cdot T \dot{E}_{78}}{2 \cdot \omega_{1}}
$$




$$
\begin{gathered}
\frac{\omega_{8 e}}{\omega_{1}}=\frac{T \dot{E}_{78}}{\omega_{1}}+\frac{z_{7}}{z_{8}} \cdot \frac{\omega_{7 e}}{\omega_{1}}+\frac{\omega_{p e}}{\omega_{1}} \cdot\left(1-\frac{z_{7}}{z_{8}}\right) \\
\frac{\omega_{9 e}}{\omega_{1}}=\frac{T \dot{E}_{p 9}}{\omega_{1}}+\frac{z_{p}}{z_{9}} \cdot \frac{\omega_{p e}}{\omega_{1}}
\end{gathered}
$$

In Eqs. (7-16), $T \dot{E}_{i j}$ is the derivative of the transmission error of the gear " $i j$ " and $\omega_{i e}$ is the angular speed of the gear " $i$ " affected by the transmission errors.

\section{Dynamic Aspects}

The cutting force when hobbing a gear is variable and quite complicated to calculate.

Many authors have written papers regarding the way to calculate the cutting force using various methods (Bostan et al. 2001; Abood, 2002; Bostan et al. 2004a; Bostan et al. 2004b; Bouzakis et al. 2008; Alazar et al. 2011; Bostan et al. 2011; Bostan et al. 2013; Iliescu, 2013; Rusu, 2015; Sabkhi et al. 2015; Hrytsay et al., 2019; Mazuru, 2019; Yang, 2019; Tabacaru).

The cutting force depends on the following factors: rotation speed of the hob, geometry of the hob, the material and the dimensions of the workpiece, the cutting regime of the hobbing process.

The technological torque acting on the workpiece can be approximated as following:

$$
M_{t 1}=C_{9} \cdot F_{0}+C_{9} \cdot F \cdot \sin \left(k_{1} \cdot \omega_{11} \cdot t\right)
$$

Similarly, the technological torque acting on the hob can be approximated as following:

$$
M_{t 2}=C_{11} \cdot F_{0}+C_{11} \cdot F \cdot \sin \left(k_{1} \cdot \omega_{11} \cdot t\right)
$$

In Eqs. (17) and (18), $C_{9}, C_{11}, F_{0}, F$ and $k_{l}$ are quantities that depend on geometry of the hob, the material and the dimensions of the workpiece, the cutting regime of the hobbing process and $\omega_{11}$ is the rotation speed of the hob.

If adopting, for the complex gear in Fig. 1, a "reducing element" dynamic model with rotation motion, with the gear $z_{l}$ as reducing element, then the differential motion equation for this dynamic model can be written as following: 


$$
J_{r e d} \cdot \frac{d \omega_{1}}{d t}+\frac{\omega_{1}^{2}}{2} \cdot \frac{d J_{r e d}}{d \varphi_{1}}=M_{r e d}
$$

In relation (19), $J_{\text {red }}$ is the reduced inertia moment of the dynamic model, which can be written as:

$$
\begin{aligned}
& J_{r e d}=J_{1}+J_{2} \cdot\left(\frac{\omega_{2 e}}{\omega_{1}}\right)^{2}+J_{3} \cdot\left(\frac{\omega_{3 e}}{\omega_{1}}\right)^{2}+J_{11} \cdot\left(\frac{\omega_{11 e}}{\omega_{1}}\right)^{2}+J_{4} \cdot\left(\frac{\omega_{4 e}}{\omega_{1}}\right)^{2}+ \\
& J_{5} \cdot\left(\frac{\omega_{5 e}}{\omega_{1}}\right)^{2}+J_{6} \cdot\left(\frac{\omega_{6 e}}{\omega_{1}}\right)^{2}+J_{7} \cdot\left(\frac{\omega_{7 e}}{\omega_{1}}\right)^{2}+J_{p} \cdot\left(\frac{\omega_{p e}}{\omega_{1}}\right)^{2}+ \\
& n_{8} \cdot J_{8} \cdot\left(\frac{\omega_{8 e}}{\omega_{1}}\right)^{2}+n_{8} \cdot m_{8} \cdot\left(\frac{\omega_{p e} \cdot r_{67}}{\omega_{1}}\right)^{2}+J_{9} \cdot\left(\frac{\omega_{9 e}}{\omega_{1}}\right)^{2}
\end{aligned}
$$

where $\frac{\omega_{i e}}{\omega_{1}}$ can be calculated with Eqs. (6-16), $J_{i}$ is the moment of inertia of element " $i$ ".

The reduced moment $M_{\text {red }}$ in Eq. (19) can be written as:

$$
M_{r e d}=M_{m}-M_{t 1} \cdot \frac{\omega_{9 e}}{\omega_{1}}-M_{t 2} \cdot \frac{\omega_{11 e}}{\omega_{1}}
$$

In Eq. (21), $M_{m}$ is the motor torque of the motor driving the complex gear. If this motor is an alternative current motor, there can be approximated:

$$
M_{m}=\frac{M_{n} \cdot\left(\omega_{1}-\omega_{s}\right)}{\omega_{n}-\omega_{s}}
$$

where $M_{n}$ is the nominal torque of the electrical motor, $\omega_{n}$ is the nominal angular speed of the electrical motor, $\omega_{s}$ is the synchronism angular speed of the electrical motor.

Considering the Eqs. (17), (18), (21), (22), there results:

$$
M_{\text {red }}=\frac{M_{n} \cdot\left(\omega_{1}-\omega_{s}\right)}{\omega_{n}-\omega_{s}}-\left(C_{9} \cdot \frac{\omega_{9 e}}{\omega_{1}}+C_{11} \cdot \frac{\omega_{11 e}}{\omega_{1}}\right) \cdot\left[F_{0}+F \cdot \sin \left(k_{1} \cdot \omega_{11} \cdot t\right)\right]
$$

For a specific gear hobbing case, if knowing the transmission errors for all the gears in the mechanism, the driving electric motor and the parameters of 
the cutting regime of hobbing process, then $J_{\text {red }}$ and $M_{\text {red }}$ in Eq. (19) can be calculated. Then, the differential motion equation (19), can be numerically integrated, resulting the real angular speed $\omega_{1}$.

In this way, the real motion of the complex gear depending on the cutting forces and the transmission errors of the gears can be determined.

It can be observed that, due to transmission errors, the reduced moment of inertia $J_{r e d}$ is not constant,

$$
J_{\text {red }}=J_{\text {red }}\left(\varphi_{1}\right)
$$

Also, the reduced torque $M_{\text {red }}$ is a function of time, position and speed:

$$
M_{\text {red }}=M_{\text {red }}\left(t, \varphi_{1}, \omega_{1}\right)
$$

\section{Conclusions}

In the paper, a dynamic study, based on researches described in a previous paper of the same authors (Merticaru and Merticaru, 2020), is developed.

The transmission errors of a complex gear and the cutting forces of a gear hobbing process are considered to conceive the dynamic model. The differential equation of motion is written and some discussions are made.

Due to transmission errors, the reduced moment of inertia $J_{\text {red }}$ is not constant and also the reduced torque $M_{\text {red }}$ is a function of time, position and speed.

The study in the paper might be useful for those who want to design such kind of gear transmissions and to calculate a specific gear hobbing cutting regime, to obtain better quality for machined gears.

Some future research development directions are intended to be followed, such as models validation through computerized modeling and simulation and also through some physical experiments.

\section{REFERENCES}

Abood A., Dynamic Analysis of the Cutting Forces in Gear Hobbing - PhD Thesis, Univ. of Newcastle, UK, 2002.

Alazar A.S., Werner M., Nicolescu C.M., Development of Cutting Force Measurement for Gear Hobbing, Proc. of the ASME 2011 Int. Design Eng. Techn. Conf. \& Computers and Inform. in Eng. Conf., IDETC/CIE 2011, Washington DC, USA, 8, 48121. 
Atanasiu V., Rozmarin C., Leohchi D., Iacob M.R., Robust Design for Minimization of Dynamic Transmission Error, Bul. Inst. Polit. Iaşi, LVI(LX), 4A, s. Constr. Maș., 219-226 (2010).

Bostan I., Mazuru S., Scaticailov S., Modelul de calcul al componentei radiale a forței de aşchiere la rectificarea angrenajelor. Conf. internaţ. „Tehnologii Moderne, Calitate, Restructurare”, TMCR 2001, Chişinău, Rep. Moldova, 3, 280-283.

Bostan I., Mazuru S., Vaculenco M., Aprecierea calităţii organelor de maşini la etapa de pregătire tehnologică a producţiei, Bul. Inst. Polit. Iaşi, LIV, Vc, s. Constr. Maș., 749-752 (2004).

Bostan I., Toca A., Mazuru S., Scaticailov S., Cercetarea variaţiei secţiunii transversale teoretice a aşchiilor dintre sculă şi roata dinţată conică precesională la rectificare şi frezare, Bul. Inst. Polit. Iaşi, LIV, Vc, s. Constr. Maș., 753-756 (2004).

Bostan I., Mazuru S., Botnari V., Kinetic Process of Teeth Grinding, 15th International Conference of Modern Technologies, Quality and Innovation, ModTech 2011, Vadul lui Voda, Rep. Moldova, 121-124.

Bostan I., Mazuru S., Scaticailov S., Technologies for Precessional Planetary Transmissions Toothing Generation, Tehnomus J., 20, 226-233 (2013).

Bouzakis K.D., Lili E., Michailidis N., Friderikos O., Manufacturing of Cylindrical Gears by Generating Cutting Processes: A Critical Synthesis of Analysis Methods, CIRP Annals - Manuf. Technol., 57, 676-696 (2008).

Hrytsay I., Stupnytskyy V., Topchii V., Improved Method of Gear Hobbing Computer Aided Simulation, Arch. of Mech. Eng., 66, 4, 475-494 (2019).

Iliescu M., Tehnologii de fabricare a componentelor mecanice ale roboţilor industriali elemente fundamentale, Ed. Printech, București, 2013.

Kučera P., Píštěk V., Prokop A., Řehák K., Transmission Error Analysis for HeavyDuty Gearbox, Vibroeng. Procedia, 18, 113-116 (2018).

Mazuru S., Procedee tehnologice de generare a profilurilor nestandarde ale angrenajelor precesionale - Teza abilitare, Univ. Tehn. a Moldovei, Chişinău, 2019.

Merticaru E., Merticaru V.jr., A Dynamic Study of a Complex Gear Transmission, ACME 2020, IOP Conf. Ser.: Mater. Sci. Eng., 997, 012078 (2020).

Merticaru E., Merticaru V., Merticaru V.jr., Caracteristicile cinematico-dinamice ale mecanismelor, partea 2, Ed. Performantica, Iași, 2014.

Merticaru E., Merticaru V.jr., Fenomene dinamice în funcționarea mecanismelor cu came, Ed. Performantica, Iași, 2004.

Merticaru V., Probleme dinamice ale funcționării mecanismelor, Ed. Junimea, Iași, 1991.

Merticaru V., Merticaru E., Merticaru V.jr., Caracteristicile cinematico-dinamice ale mecanismelor, partea 1, Ed. PIM, Iași, 2009.

Raghuraman N., Jain S., Glinsky C., Prediction of Dynamic Factors for Helical Gears in a High-Speed Multibody Gearbox System, The J. of Gear Manuf., 35, 3, 4454 (2018).

Rusu O.T., Contribuții privind studiul procesului de frezare cu viteze mari de așchiere, pe centre de prelucrare - Teză de doctorat, Univ. Tehn. „Gheorghe Asachi” din Iaşi, Romania, 2015. 
Sabkhi N., Pelaingre C., Barlier C., Moufki A., Nouari M., Characterization of the Cutting Forces Generated During the Gear Hobbing Process: Spur Gear, $15^{\text {th }}$ CIRP Conf. on Modelling of Machining Op., Procedia CIRP 31, 411-416 (2015).

Tabacaru V., Indrumar 1 EMCO Concept MILL 55: Caracteristici mecanice. Elemente de tehnologie. Comenzi Emco-Siemens. Operare și programare, Univ. Dunărea de Jos, Galați, http://www.if.ugal.ro/CD/SIP_SFF_SECN_Capitole123.pdf.

Vispute B., Borse R., Sonar R., Jagtap T., Detection of Gear Tooth Defects by Using MATLAB \& FEA Technique, IJARIIE, 3, 2, 951-960 (2017).

Yang Y., Li X., Zou Z., Zeng L., Wang L., Theoretical Analysis of the Influence of Workpiece Spindle Vibration Displacement on Machining Accuracy of Gear Hobbing Machine, J. of Vibroeng., 21, 2, 286-300 (2019).

** Bazele generării suprafeţelor. Prelucrarea prin aşchiere a roţilor dinţate, https://www.cmmi.tuiasi.ro/docs/cursuri/Danturarea\%20rotilor\%20dintate.pdf.

\section{MODELE ALE INFLUENȚELOR ERORILOR DE TRANSMITERE ȘI ALE FORȚELOR DINTR-UN PROCES DE DANTURARE ASUPRA UNEI TRANSMISII COMPLEXE CU ANGRENAJE}

(Rezumat)

Lucrarea prezintă un demers teoretic de cercetare care presupune un studiu asupra dinamicii unei transmisii complexe cu angrenaje. Analiza cinematicii ia în considerare erorile de transmisie din angrenajele componente. De asemenea, evaluarea parametrilor dinamici din modelul propus ia în considerare forțele de așchiere dintr-un proces de danturare care poate avea în lanțul cinemtic de acționare o asemenea transmisie complexă. Modelul propus include obținerea ecuației diferențiale a energiei cinetice. Totodată, sunt formulate unele discuții privind mecanismul supus studiului de caz. Practic, sunt propuse ca rezultate livrabile ale studiului, modele ale influențelor erorilor de transmisie din angrenaje și ale forțelor de așchiere la dantuarea prin generare, asupra transmisiei complexe analizate. Sunt formulate, în final, unele concluzii ale studiului. Aspectele analizate și prezentate în lucrare au utilitate pentru proiectarea unor asemenea transmisii complexe și pentru calculul parametrilor unor procese de danturare prin generare. 